\title{
Environmental Scanning Practices and Structure: An Empirical Study of Industrial Tunisian Group
}

\author{
Afef Znaidi ${ }^{1} \&$ Dorra Gherib ${ }^{2}$ \\ ${ }^{1}$ IHEC, Carthage University, Tunisia, Tunisia \\ ${ }^{2}$ College of Business, University of Jeddah, Jeddah, Saudi Arabia \\ Correspondence: Dorra Gherib, College of Business, HR Department, College of Business, University of Jeddah, \\ Saudi Arabia. E-mail: dorra.gherib@gmail.com \\ Received: May 13, 2020 \\ Accepted: June 13, 2020 \\ Online Published: June 18, 2020 \\ doi:10.5430/rwe.v11n3p180 \\ URL: https://doi.org/10.5430/rwe.v11n3p180
}

\begin{abstract}
Background/Objectives: The main purpose of the research is to study the influence of the structural specificities on the environmental scanning practices of industrial Tunisian groups. This research presents the direct effect of structural specificity on environment scanning practices and verify the existence of linear relationships between centralization, formalization and complexity of the structure and the variables of the environmental scanning practices.
\end{abstract}

Methods/Statistical. Methodological tools of the research methods were quantitative, a survey based on a questionnaire is conducted with a sample of the relevant population, namely, subsidiaries of Tunisian industrial groups. The number of managers to whom we sent the questionnaire amounted to 283, a total of 120 usable questionnaires were collected. The overall response rate was $42.4 \%$. The collected questionnaires were then processed using specialized SPSS software. With regard to the purification of measuring instruments, exploratory factor analysis.

Findings: The results of the hypothesis validation relating structure centralization and the environmental scanning practices mean that a weak centralization, a decentralization of decision-making. The second series of hypotheses concerning the link between structure formalization and environmental scanning practices, we were able to confirm the existence of all the relationships provided for between the formalization and the environmental scanning practices. The hypotheses concerning the relationship between the vertical complexity and the environmental scanning practices were rejected.

Improvements/Applications: The contributions of scanning environment practices at the corporate level and at the level of group subsidiaries, and stimulate the efforts made by companies in the field of scanning environment.

Keywords: the scanning environment practices, centralization, formalization, complexity

\section{Introduction}

As part of this research, we wanted to go beyond the descriptive analysis of the environmental scanning practices (ESP) of the firm by proposing an explanatory analysis of these practices through the identification of the organizational factors, and in particular those which are structural and likely to influence them. In this context, several authors consider that organizational factors have an influence on ESP by acting on information needs, information search, and information use. Business strategy (Choo, 1999; Beal, 2000; Raymond et al, 2001; Brouard, 2000; 2005); organizational structure (Lesca, 1983; Vergnaud-Schaeffer, 1993; Chapus and Lesca, 1996; Kourteli, 2000; Brouard, 2000, 2005; Cohen, 2006) and organizational culture (Ballaz, 1993; Chapus and Lesca, 1996; Roiron and Lesca, 1996; Julien et al, 1997) are among the factors often mentioned in the literature. As part of this work, we have chosen to understand the organizational determinants of ESP through the firm's structural specificities.

The organizational theory is a vast area of research. We will base this section on the essentials of the basic concepts related to this theory. The contingency theory emerged in the 1970s recognizing that the best way to structure an organization depends on the specific situation, that is, the internal and external conditions of the organization. When the organization changes the role of the structure and the functions realign with the new conditions (Narman et al 2014).

Some authors insist on the importance of favoring transversal modes of coordination, by informal communication, to 
vertical, formal and hierarchical modes of coordination, and specify that the leaders, who continue to monitor the environment and environmental scanning practices (ESP) by having organizational structures and outdated procedures, may draw wrong conclusions about their environment and make the wrong decisions (Donaldson, 1982; Vergnaud-Schaeffer, 1993; Kourteli, 2000; Gartiser et al, 2004). At this level, it is necessary to operationalize the firm's structural specificities which are likely to influence ESP in order to allow their perception on the field. It is also worth noting that in our study, the organizational structure is approached from the angle of attributes by aligning with the works of contingency theorists (Desreumaux, 1989; Lawrence and Lorsch, 1989; Dubost, 1999). Some structural attributes are often dealt with in the previous studies, namely, specialization, vertical differentiation, formalization, and centralization (Mintzberg, 1982; Miller, 1987; Bergeron et al, 2004).

In this article and in line with the works of Hatch (2000), we retain three main variables for the operationalization of the firm's structural specificities: centralization, formalization, and structural complexity. Centralization refers to the locus of authority and decision-making (Bergeron et al, 2004). According to Hatch (2000), it answers the question of the hierarchical level at which decisions are made. The author observes, for this purpose, the difficulty of measuring the degree of centralization because this latter might include different types of decisions. Formalization reflects the extent to which organizational activities are governed by explicit rules, regulations, policies, and procedures (Hatch, 2000). It thus restricts the employees' activities to those prescribed in advance (Pleshko and Nickerson, 2008). Complexity refers to both the horizontal and vertical differentiation at the level of the organizational structure. The horizontal differentiation is measured by the degree to which the firm's tasks, units and roles are allocated according to functions, positions, or divisions (Bradish, 2003). Vertical differentiation is measured by the number of hierarchical levels that an organization includes (Hatch, 2000).

We point out that we have largely approached this concept in the context of previous works (Znaidi et al, 2018, Znaidi and Gherib, 2019) aiming at improving the understanding of environmental scanning through its practical manifestations at the firm's level. Thus, throughout our work, we base ourselves on the results put forward by these previous studies about variables relating to ESP. These are the variables retained following an exploratory qualitative study and a confirmatory quantitative study carried out with leaders and managers within groups of Tunisian firms.

According to these studies, ESP can be approached through three possible notions. The first notion is object-oriented. It refers to the field of intelligence application, that is to say changes such as signals, events or even trends which are under the firm's observation and analysis (Choo, 2002; McGee and Sawyerr, 2003; Strandholm and Kumar, 2003; Brouard and Larivet, 2007; Dishman and Calof, 2008). Hence the variable relating to the types of information sought. The second notion is mode oriented. It corresponds to the use of information sources and networks to learn about the environment. These sources can be formal or informal, internal, or external (Choo, 1999; 2002; Raymond et al, 2001; Julien and Ramangalahy, 2003; McGee and Sawyerr, 2003; Albright, 2004, Aldehayyat 2014, Du Toit 2016). It is the variable relating to the sources of information used. The third notion is organization oriented. It translates managerial practices in terms of information management. It relates to the diversity of practices used to manage the collection, analysis and dissemination of information. It also refers to the formalization of these practices (Kumar et al, 2001; Dishman and Calof, 2008; Amabile and Guechtouli, 2008; Amabile et al, 2011; Guechtouli, 2014). This notion, therefore, involves the variables relating to the methods of collecting, analyzing, distributing, and storing information, but also the variable relating to the formalization of information management.

This study therefore addresses the following question: To what extent can structural specificities influence the firm's environmental scanning practices (ESP)? The rest of this work is structured in three parts. First, we introduce the theoretical framework as well as the model and the research hypotheses which have been dealt with. Next, we will describe the methodological choices. Finally, we display the results of this study before discussing them.

\section{Literature Review and Research Design}

Retaining centralization versus decentralization as a structural determinant of ESP is justified by the fact that decentralization is often assimilated to a tool of business relevance making it possible to define the firm's actions best suited to the nature of the environment and the firm resources. This leads to the following hypothesis: H1: Structure centralization influences environmental scanning practices

The sub-hypotheses arising from the H1 hypothesis are:

H1a: The centralization of the structure influences the types of information sought

H1b: The centralization of the structure influences the sources of information used

H1c: The centralization of the structure influences information collection methods 
H1d: The centralization of the structure influences information analysis methods

H1e: The centralization of the structure influences the methods of disseminating information

H1f: Centralization of structure influences information storage methods

H1g: The centralization of the structure influences the formalization of information management

Formalization provides an account of the extent to which explicit rules, regulations and procedures govern the organization's activities. It tends to reduce the discretion of employees in carrying out their activities while increasing the sense of control that managers have over them (Hatch, 2000; Pleshko and Nickerson, 2008). The hypothesis follows: $\mathrm{H} 2$ : The formalization of the structure influences the environmental scanning practices.

The sub-hypotheses arising from the general $\mathrm{H} 2$ hypothesis are formulated as follows:

$\mathrm{H} 2 \mathrm{a}$ : The formalization of the structure influences the types of information sought

$\mathrm{H} 2 \mathrm{~b}$ : Formalization of structure influences the sources of information used

H2c: Formalization of structure influences information-gathering methods

H2d: Formalization of structure influences information analysis methods

H2e: Formalization of structure influences methods of disseminating information

H2f: Formalization of structure influences information storage methods

$\mathrm{H} 2 \mathrm{~g}$ : Formalization of structure influences the formalization of information management

We therefore believe that a high degree of vertical complexity of the structure can affect the company's ESP and the recovery and dissemination of information to the relevant stakeholders. Hence the following general hypothesis: H3: The complexity of the structure influences the environmental scanning practices.

The sub-hypotheses arising from the $\mathrm{H} 3$ hypothesis are formulated as follows:

H3a: The complexity of the structure referring to its vertical differentiation influences the types of information sought

$\mathrm{H} 3 \mathrm{~b}$ : The complexity of the structure referring to its vertical differentiation influences the sources of information used

$\mathrm{H} 3 \mathrm{c}$ : The complexity of the structure referring to its vertical differentiation influences information collection methods

H3d: The complexity of the structure referring to its vertical differentiation influences information analysis methods

H3e: The complexity of the structure referring to its vertical differentiation influences the methods of dissemination of information

H3f: The complexity of the structure referring to its vertical differentiation influences information storage methods

$\mathrm{H} 3 \mathrm{~g}$ : The complexity of the structure referring to its vertical differentiation influences the formalization of information management

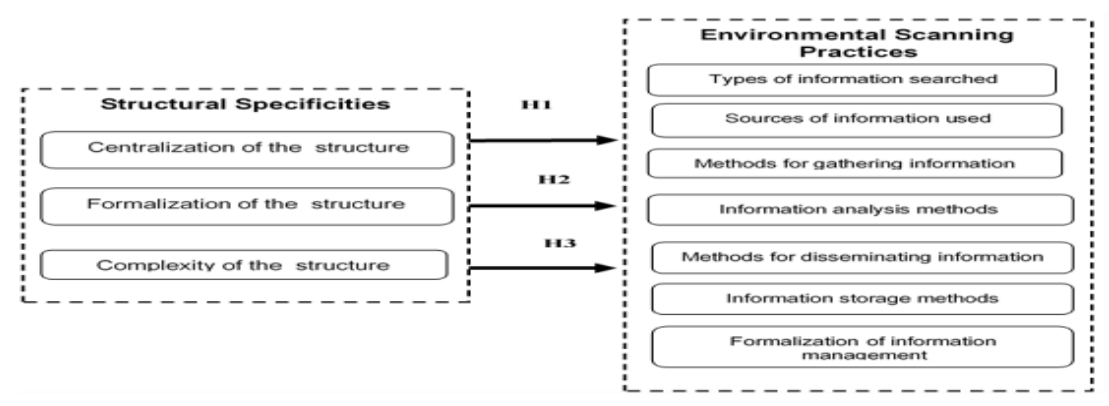

Figure 1. Proposed conceptual framework

\section{Methodology and Research Methods}

As part of a quantitative study, a survey based on a questionnaire is conducted with a sample of the relevant population, namely, subsidiaries of industrial Tunisian groups. The objective of this phase is to study and test the possible relationships between the variables to be explained (variables related to ESP) and explanatory variables (variables related to structure). With regard to the purification of measuring instruments, exploratory factor analysis 
(EFA) as well as the alpha coefficient are not capable of giving information on the homogeneity of a multidimensional measuring instrument (Gerbing and Anderson, 1988, Carricano and Poujol, 2008). However, given the one-dimensional nature of the measurement scales used in this study, it seems justified to select only these two purification methods without resorting to confirmatory factor analysis (CFA). The methodological framework adopted in this study also provides for a validation phase. This includes the final data collection stage followed by two successive stages relating to the assessment of the reliability and validity of the measuring instruments.

Concerning the items used in the final questionnaire to measure the variables relating to ESP, we based ourselves on the results advanced in the framework of two previous studies (Znaidi et al 2018; Znaidi and Gherib 2019). The dimensions of ESP were retained following an exploratory qualitative study carried out with various managers within groups of Tunisian firms (Znaidi et al 2018). The measurement scales reflecting these dimensions were first purified, then were subjected to a set of tests to ensure their reliability and validity (Znaidi and Gherib 2019). The final questionnaire which we ended up with has a total of 25 items to measure the ESP variables and 12 items to measure the structural specificities variables. The number of managers to whom we sent the questionnaire amounted to 283 . A total of 120 usable questionnaires were collected. The overall response rate was $42.4 \%$. The collected questionnaires were then processed using specialized SPSS software.

Table 1. Synthesis of measurement scales

\begin{tabular}{|c|c|c|}
\hline Model Variable & Item Descriptions & Code \\
\hline \multirow{3}{*}{$\begin{array}{l}\text { Types of needed information } \\
\text { (Adapted from Raymond et al., } \\
\text { 2001) } \\
\begin{array}{c}1=\text { never, } 2=\text { rarely, } 3=\text { often } \\
4=\text { Very often, } 5=\text { always }\end{array}\end{array}$} & $\begin{array}{l}\text { Financial and human resources information (cost and } \\
\text { cost-effectiveness of technological changes and other investments, } \\
\text { recruitment and staff training needs): }\end{array}$ & TNI1 \\
\hline & $\begin{array}{l}\text { Information on innovations (product innovations, processes and } \\
\text { equipment) }\end{array}$ & TNI2 \\
\hline & $\begin{array}{l}\text { Marketing information (identification of potential markets, suppliers } \\
\text { and competitors) }\end{array}$ & TNI3 \\
\hline \multirow{4}{*}{$\begin{array}{l}\text { Sources of used information } \\
\text { (Adapted from Daft et al., 1988) } \\
1=\text { never, } 2=\text { rarely, } 3=\text { often } \\
4=\text { Very often, } 5=\text { always }\end{array}$} & $\begin{array}{l}\text { External sources of impersonal information (publications, } \\
\text { newspapers, magazines, newsletters, books, documents or comments } \\
\text { collected in exhibitions, conference, ...) }\end{array}$ & SIU1 \\
\hline & $\begin{array}{l}\text { Personal external sources of information (contacts with clients, } \\
\text { suppliers, bankers, consultants and contacts at unforeseen } \\
\text { meetings...) }\end{array}$ & SIU2 \\
\hline & $\begin{array}{l}\text { Internal sources of impersonal information (documents existing in the } \\
\text { company: activity reports, specific studies, client and supplier } \\
\text { files...) }\end{array}$ & SIU3 \\
\hline & $\begin{array}{l}\text { Personal internal sources of information (contacts with employees, } \\
\text { subordinates and anyone belonging to the company...) }\end{array}$ & SIU4 \\
\hline \multirow{3}{*}{$\begin{array}{l}\text { Information collected methods } \\
\begin{array}{c}1=\text { never, } 2=\text { rarely, } 3=\text { often } \\
4=\text { Very often, } 5=\text { always }\end{array}\end{array}$} & $\begin{array}{l}\text { Collection through contacts (meeting or visit with customers, } \\
\text { suppliers, representatives, sellers...) }\end{array}$ & ICM1 \\
\hline & $\begin{array}{l}\text { Collection through surveys (household surveys, satisfaction surveys, } \\
\text { awareness surveys...) }\end{array}$ & ICM2 \\
\hline & $\begin{array}{l}\text { Collection through the consultation of written or electronic } \\
\text { documentation (reading specialized journals, Internet...) }\end{array}$ & ICM3 \\
\hline \multirow{4}{*}{$\begin{array}{l}\text { Information analysis methods } \\
\begin{array}{c}1=\text { never, } 2=\text { rarely, } 3=\text { often } \\
4=\text { Very often, } 5=\text { always }\end{array}\end{array}$} & $\begin{array}{l}\text { Cross-referencing analysis (validation of information collected from } \\
\text { other information and sources) }\end{array}$ & IAM1 \\
\hline & $\begin{array}{l}\text { Comparative analysis (comparative studies with competition, } \\
\text { benchmarking...) }\end{array}$ & IAM2 \\
\hline & Analysis by simulation (modeling ...) & IAM3 \\
\hline & Analysis by elaboration of scenarios & IDM1 \\
\hline $\begin{array}{l}\text { Information disseminated } \\
\text { methods }\end{array}$ & $\begin{array}{l}\text { Disseminated through meetings (management meetings, service } \\
\text { meetings, quality circle...) }\end{array}$ & IDM2 \\
\hline
\end{tabular}




\begin{tabular}{|c|c|c|}
\hline \multirow[t]{3}{*}{$\begin{array}{c}1=\text { never, } 2=\text { rarely, } 3=\text { often } \\
4=\text { Very often, } 5=\text { always }\end{array}$} & $\begin{array}{l}\text { Disseminated by written media (memos, debriefings, mission } \\
\text { reports...) }\end{array}$ & IDM3 \\
\hline & $\begin{array}{l}\text { Disseminated by Electronic broadcast (Intranet, internal electronic } \\
\text { messaging...) }\end{array}$ & IDM4 \\
\hline & Disseminated by phone, fax ... & ISM1 \\
\hline \multirow{3}{*}{$\begin{array}{c}\text { Information storage methods } \\
\begin{array}{c}1=\text { never, } 2=\text { rarely, } 3=\text { often } \\
4=\text { Very often, } 5=\text { always }\end{array}\end{array}$} & Storage by paper classification. & ISM2 \\
\hline & Storage by building electronic databases. & ISM3 \\
\hline & Storage by memory of know-how in the form of procedures. & FIM1 \\
\hline \multirow{4}{*}{$\begin{array}{c}\text { Formalization of information } \\
\text { management } \\
\text { (Adapted from Salvetat and Le } \\
\text { Roy, 2007) } \\
\begin{array}{c}1=\text { never, } 2=\text { rarely, } 3=\text { often } \\
4=\text { Very often, } 5=\text { always }\end{array}\end{array}$} & $\begin{array}{l}\text { For the company, information management (collection, analysis, } \\
\text { dissemination and storage) is carried out within a dedicated } \\
\text { department, department... }\end{array}$ & FMI2 \\
\hline & $\begin{array}{l}\text { For the company, information management is subject to written } \\
\text { procedures, methods (internal documents...). }\end{array}$ & FIM3 \\
\hline & $\begin{array}{l}\text { The company allocates a specific budget for information } \\
\text { management. }\end{array}$ & FIM4 \\
\hline & $\begin{array}{l}\text { In the field of information management, the company has a } \\
\text { permanent working group dedicated to this management. }\end{array}$ & FIM5 \\
\hline
\end{tabular}

Source: A. Znaidi and D. Gherib (2019)

\subsection{Data Collection Procedure, and Data Analysis}

In the following we present the data collection procedure, and data analysis. At first, the results of the purification of the measurement scales which have been subjected to a set of tests to ensure their reliability and validity. For the validity of the measurement scales, we mainly refer to Carricano and Poujol's (2008) recommendations: the Bartlett Sphericity test; it examines the correlation matrix in its entirety, and provides the probability of the null hypothesis according to which all correlations are zero. The KMO index indicates whether the data are consistent together and are suitable for factor analysis. Thus the KMO values between 0.3 and 0.7 represent acceptable factor solutions (Table 2).

Table 2. KMO and Bartlett Test Results

\begin{tabular}{|c|c|c|c|c|}
\hline \multirow[t]{2}{*}{ Items } & \multirow[t]{2}{*}{ Indice KMO } & \multicolumn{3}{|c|}{ Bartlett test } \\
\hline & & $\begin{array}{c}\text { Chi-square } \\
\chi^{2}\end{array}$ & Ddl & Sig \\
\hline Centralization of the structure & 0,653 & 41.578 & 10 & ,000 \\
\hline Formalization of the structure & 0,712 & 19.848 & 6 & ,003 \\
\hline Complexity of the structure & 0,637 & 31,938 & 3 & ,000 \\
\hline
\end{tabular}

We retain the variance percentage criterion according to which, we observe the cumulative percentages of the variance extracted by the successive factors. The goal is to make sure that one factor explains a significant amount of the variance. The extraction should be stopped when $60 \%$ of the explained variance is extracted. Cronbach's alpha coefficient assesses the internal consistency of the scale. An acceptable alpha coefficient must be between 0.6 and 0.8, thus authorizing the continuation of the analysis (Evrard et al 2003) (see Table 3). 
Table 3. Results of the explained total variance analysis and reliability test

\section{Total Variance Explained}

Components

\section{Initial own values $\quad$ Extracting Squares from \\ Selected Factors}

\begin{tabular}{|c|c|c|c|c|c|c|c|}
\hline Total & $\%$ var & $\%$ Cum. & Total & $\%$ var & $\%$ Cum & $\begin{array}{c}\text { Alpha } \\
\text { Cronbach } \\
\text { coef }\end{array}$ & $\begin{array}{c}\text { No. } \\
\text { Eléments }\end{array}$ \\
\hline
\end{tabular}

Reliability test

$\mathbf{0 , 8 8}$

\begin{tabular}{|c|c|c|c|c|c|c|c|c|}
\hline Centralization of the structure & & & & & & & $\mathbf{0 , 8 8}$ & 5 \\
\hline $\begin{array}{l}\text { The number of employees } \\
\text { required }\end{array}$ & 3,467 & 69,34 & 69,34 & 3,46 & 69,34 & 69,34 & & \\
\hline Conflicts between workers & 610 & 12,20 & 81,54 & & & & & \\
\hline Overtime in workshops &, 528 & 10,57 & 92,11 & & & & & \\
\hline $\begin{array}{llll}\begin{array}{l}\text { Delivery dates and order } \\
\text { priority }\end{array} & & & \\
\end{array}$ & 319 & 6,37 & 98,48 & & & & & \\
\hline Production planning & 076 & 1,511 & 100,0 & & & & & \\
\hline Formalization of the structure & & & & & & & 0.81 & 4 \\
\hline Information brochures & 2,574 & 64,33 & 64,33 & 2,57 & 64,33 & 64,33 & & \\
\hline $\begin{array}{lll}\begin{array}{l}\text { Number } \\
\text { brochures }\end{array} & \text { information } \\
\end{array}$ & 802 & 20,05 & 84,38 & & & & & \\
\hline The chart & ,396 & 9,890 & 94,27 & & & & & \\
\hline Job definition & 229 & 5,722 & 100,0 & & & & & \\
\hline Complexity of the structure & & & & & & & $\mathbf{0 , 8 9}$ & 3 \\
\hline Office profile & 2,480 & 82,67 & 82,67 & 2,48 & 82,67 & 82,67 & & \\
\hline Innovative profile &, 456 & 15,193 & 97,86 & & & & & \\
\hline Support profile & ,064 & 2,136 & 100,0 & & & & & \\
\hline
\end{tabular}

\section{Results, Analysis and Discussion}

\subsection{The Descriptive Analysis}

According to the Miller and Droge (1986) measurement scale adopted in this study, the degree of structure centralization results in the location of the hierarchical level having the power to make certain decisions. We specify in what follows the hierarchical levels which are, in most cases, relative to making five types of decisions.

Table 4. Degree of structure centralization

\begin{tabular}{|c|c|c|c|c|c|}
\hline & CEO & $\begin{array}{l}\text { Director } \\
\text { Manager }\end{array}$ & $\begin{array}{l}\text { Department } \\
\text { director } \\
\text { /function }\end{array}$ & $\begin{array}{c}\text { Director/ } \\
\text { Head of } \\
\text { department }\end{array}$ & Operational \\
\hline & 1 & 2 & 3 & 4 & 5 \\
\hline $\begin{array}{l}\text { The number of employees } \\
\text { required }\end{array}$ & 0 & 6,7 & 20,0 & 46,7 & 26,7 \\
\hline Conflicts between workers & 0 & 10,0 & 16,7 & 46,7 & 26,7 \\
\hline Overtime in workshops & 0 & 9,2 & 13,3 & 41,7 & 35,8 \\
\hline Delivery dates and order priority & 0 & 10,0 & 16,7 & 33,3 & 40,0 \\
\hline Production planning & 0 & 6,7 & 10,0 & 46,7 & 36,7 \\
\hline
\end{tabular}

The results displayed in the table above indicate that with regard to the number of employees required at the subsidiary 
level, disputes between workers, overtime in the workshops, and production planning, the decisions are generally made by the assistant manager or the head of the department, the head of the unit, or the team leader in most of the examined subsidiaries. In fact, for the first and second type of decision relating to human resources management, $46.7 \%$ of subsidiaries consider that they can be made by hierarchical levels far below the CEO. With regard to the additional hours in the workshops, the choice made by $41.7 \%$ of the subsidiaries, relating to the hierarchical level which has the power to make this type of decision, can be explained by the fact that by being linked to the management of the production and the organization of its resources, this decision often rests with the functional managers associated to this activity. This same justification can also be given to the response of $46.7 \%$ of the subsidiaries which have chosen the same hierarchical level for decisions relating to production planning. However, it should be noted that for these decisions, $36.7 \%$ of the subsidiaries say that they can be made by operational staff, and the same answer is given by $35.8 \%$ of the subsidiaries for decisions related to overtime in the workshops. With respect to decisions regarding delivery dates and order priority, the majority of subsidiaries (40\%) stipulate that they are generally made by the last hierarchical level considered in this study, namely, the operational staff.

Our descriptive analysis of the subsidiaries' trends in terms of structural formalization will therefore focus on these four retained aspects. Table 5 presents the percentage of subsidiaries according to their choice as to the different response methods proposed for each aspect of formalization.

Table 5. Degree of structure formalization

\begin{tabular}{lccccc}
\hline & No & One & Two & Three & Four or more \\
\hline & 1 & 2 & 3 & 4 & 5 \\
\hline $\begin{array}{l}\text { Accessibility of } \\
\text { information } \\
\text { brochures }\end{array}$ & 0 & 5,8 & 1,7 & 58,3 & 34,2 \\
\hline $\begin{array}{l}\text { Number of } \\
\text { information } \\
\text { brochures in the } \\
\text { company }\end{array}$ & 0 & 0,8 & 15,0 & 43,3 & 40,8 \\
& No & CEO & $\begin{array}{c}\text { CEO and } \\
\text { Director } \\
\text { Manager }\end{array}$ & $\begin{array}{c}\text { CEO, Director, } \\
\text { Manager and } \\
\text { Department } \\
\text { Managers }\end{array}$ & $\begin{array}{c}\text { CEO, Director, } \\
\text { Manager Department, } \\
\text { department }\end{array}$ \\
\hline & 1 & 2 & 3 & 4 & 5 \\
\hline $\begin{array}{l}\text { Accessibility of the } \\
\text { organization chart }\end{array}$ & 0 & 9,2 & 4,2 & 51,7 & 35,0 \\
\hline & No & Production & $\begin{array}{l}\text { Production } \\
\text { and office } \\
\text { employees }\end{array}$ & $\begin{array}{c}\text { Production, office } \\
\text { employes and } \\
\text { managers }\end{array}$ & $\begin{array}{c}\text { Production, office } \\
\text { employees, managers } \\
\text { and specialists }\end{array}$ \\
\hline $\begin{array}{l}\text { employees } \\
\text { with job definitions }\end{array}$ & 1 & 2 & 3 & 4 & 5 \\
\hline
\end{tabular}

The results displayed in the table above show that, in more than half of the studied subsidiaries (58.3\%), the information brochures relating to working conditions, safety standards, etc., are accessible to several employees and for $34.2 \%$ of the subsidiaries, they are accessible to all staff. The massive distribution of these information brochures reflects the desire for significant formalization of behavior within the subsidiary and the guarantee of greater transparency with regard to the staff's rights and obligations. Regarding the number of these brochures, $43.3 \%$ of the subsidiaries say that the number of information brochures they have is three, and for $40.8 \%$ of the subsidiaries, it is four 
or more. The result obtained confirms what we have already described. In fact, the desire to formalize behavior is reflected in most subsidiaries by the existence of relatively large internal documentation and by the accessibility to this documentation by as many stakeholders as possible.

For the third aspect of formalization, a large percentage of the subsidiaries in the sample $(51.7 \%)$ communicate the organizational chart to the CEO, the MD and the Directors of Departments (DD) / Divisions / Services. Finally, and with regard to tasks' definitions, the results obtained indicate that for $47.5 \%$ of the subsidiaries, tasks' definitions are provided for production employees, for office workers and for managers, and for (40\%) of the subsidiaries, even specialists are affected by these task definitions. This aspect of structural formalization is a means to better control the behaviors of the different subsidiary's stakeholders, and to guarantee the execution of tasks and activities, as they have been programmed and planned. In what follows, we present the percentages relating to the degree of presence of these two levels of structural complexity in the examined subsidiaries.

Table 6. Degree of complexity

\begin{tabular}{lcc}
\hline & High & Low \\
\hline & 1 & 2 \\
\hline Vertical complexity of the structure & 71,7 & 28,3 \\
\hline
\end{tabular}

According to the respondents' responses, $71.7 \%$ of the subsidiaries have a high degree of vertical complexity, that is to say the latter have five or more hierarchical levels. Insofar as we have seen previously, a high degree of formalization in the majority of the studied subsidiaries and the descriptive analysis indicate a high complexity. It is possible to suggest that the structures of these subsidiaries are rather bureaucratic and that they may therefore impose natural boundaries which affect communication but also the circulation and exploitation of information.

\subsection{The Relationship Between Structure and Environmental Scanning Practices}

In the following, we present the direct effect of structural specificity on environment scanning practices and we verify the existence of linear relationships between centralization, formalization and complexity of the structure and the variables of ESP : The types of needed information, the sources of used information, the methods of collected information, the methods of analysis information, the methods of disseminated information, methods of storage information and the formalization of information management.

H1: Structure centralization influences environmental scanning practices.

Table 7. Relationship between complexity and environmental scanning practices

\begin{tabular}{|c|c|c|c|c|c|}
\hline & $\mathbf{F}$ & ddl & sig. & $\mathbf{R}^{2}$ & Hypothesis H1 \\
\hline Types of needed information & 11157.335 & 3.000 & 0.000 & $60.6 \%$ & $H 1_{\mathrm{a}}$ : accepted \\
\hline Sources of used information & 4973.556 & 4.000 & 0.000 & $91.0 \%$ & $H 1_{b}:$ accepted \\
\hline $\begin{array}{l}\text { Methods of } \\
\text { collected 'information }\end{array}$ & 7179.461 & 3.000 & 0.000 & $94.9 \%$ & H1c: accepted \\
\hline $\begin{array}{l}\text { Methods of analysis } \\
\text { information }\end{array}$ & 1389.854 & 3.000 & 0.000 & $68.1 \%$ & $H 1_{d}:$ accepted \\
\hline $\begin{array}{l}\text { Methods of disseminated } \\
\text { information }\end{array}$ & 1213.198 & 4.000 & 0.000 & $70.9 \%$ & $H 1_{e}:$ accepted \\
\hline $\begin{array}{l}\text { Methods of storage } \\
\text { information }\end{array}$ & 11535.441 & 3.000 & 0.000 & $93.4 \%$ & $H 1_{\mathrm{f}}$ : accepted \\
\hline $\begin{array}{l}\text { The formalization of } \\
\text { information management }\end{array}$ & 5001.896 & 5.000 & 0.000 & $83.7 \%$ & H1 $1_{\mathrm{g}}$ : accepted \\
\hline
\end{tabular}

From the table above, we find that the asymptotic meaning is equal to 0 (less than 0.05 ), which allows us to reject the null hypothesis of independence and to confirm (H1a, H1b, H1c, H1d, H1e, H1f and H1g) hypotheses, that is to say the results obtained make it possible to consider that there is a relationship between structure centralization and ESP. 
The validation of the hypothesis, relating structure centralization and ESP, means that a weak centralization, nay, a decentralization of decision-making at the level of the subsidiary necessarily leads to the mobilization of stakeholders with different profiles, who may collect a variety of information, use several information sources and networks, and adopt a variety of methods and tools for collecting, analyzing, disseminating and storing information.

The result relating to the confirmation of the existence of a link between structure centralization versus decentralization and ESP variables is justified in the theoretical reflections of certain authors (Donaldson, 1982) who confirm that the leaders who continue monitoring the environment, collecting and processing information about it by having outdated organizational structures and procedures, may draw wrong conclusions about their environment and make bad decisions. Also, an in-depth analysis of the links between the environment and the firm aligns with Barnett and Berland's study (1999) which shows that the desire for decentralization of managers is often dependent on the degree of perceived uncertainty of the environment.

$\mathrm{H} 2$ : Structure formalization influences environmental scanning practices

Table 8. Relationship between formalization and environmental scanning practices

\begin{tabular}{|c|c|c|c|c|c|}
\hline & $\mathbf{F}$ & Ddl & sig. & $\mathbf{R}^{2}$ & Hypothesis $\mathbf{H}_{2}$ \\
\hline Types of needed information & 664.554 & 3.000 & 0.000 & $36.9 \%$ & $\mathrm{H} 2_{\mathrm{a}}$ : accepted \\
\hline Sources of used information & 192.530 & 4.000 & 0.000 & $46.7 \%$ & $H 2_{b}$ : accepted \\
\hline Methods of collected information & 434.520 & 3.000 & 0.000 & $50.0 \%$ & H2c: accepted \\
\hline Methods of analysis information & 242.229 & 3.000 & 0.000 & $46.7 \%$ & $\mathrm{H} 2_{\mathrm{d}}:$ accepted \\
\hline Methods of disseminated information & 316.268 & 4.000 & 0.000 & $37.7 \%$ & $\mathrm{H} 2_{\mathrm{e}}$ : accepted \\
\hline Methods of storage information & 315.959 & 3.000 & 0.000 & $39.7 \%$ & $H 2_{\mathrm{f}}$ : accepted \\
\hline $\begin{array}{l}\text { The formalization of information } \\
\text { management }\end{array}$ & 277.589 & 5.000 & $\mathbf{0 . 0 0 0}$ & $28.8 \%$ & H2 : accepted \\
\hline
\end{tabular}

From the table above, we find that the asymptotic significance is equal to 0 (less than 0.05 ), which allows us to reject the null hypothesis of independence and to confirm $(\mathrm{H} 2 \mathrm{a}, \mathrm{H} 2 \mathrm{~b}, \mathrm{H} 2 \mathrm{c}, \mathrm{H} 2 \mathrm{~d}, \mathrm{H} 2 \mathrm{e}, \mathrm{H} 2 \mathrm{f}$ and $\mathrm{H} 2 \mathrm{~g}$ ) hypotheses, that is to say the results obtained make it possible to consider that there is a relationship between structure formalization and ESP. The result obtained agrees with the main recommendations of the works on the interdependence between the environment and the firm structure (Mintzberg, 1982). Indeed, these works stipulate that the structural characteristics must adapt to environmental requirements, or else, they can lead to poor interpretations of the environment and bias the firm's business choices (Duncan, 1972; Vergnaud-Schaeffer, 1993; Kourteli, 2000; Boulifa-Tamboura and Ben Ammar-Mamlouk, 2009). The acceptance of the existence of a link between the structure formalization and the variables relating to ESP also agrees with the works of Messeghem (2001a). The latter confirms the importance of writing in the firm and explains that structural formalization can manifest itself through the presence of a documentary system and through the preponderance of writing in the flow of information and communication.

H3: The vertical complexity of the structure influences environmental scanning practices.

Table 9. Relationship between complexity and environmental scanning practice

\begin{tabular}{lccccc}
\hline & $\mathbf{F}$ & Ddl & sig. & $\mathbf{R}^{\mathbf{2}}$ & Hypothesis H3 \\
\hline Types of needed information & 0.403 & 3.000 & 0.751 & $0.2 \%$ & $\mathbf{H 3}_{\mathbf{a}}:$ rejected \\
\hline Sources of used information & 0.960 & 4.000 & 0.432 & $0.2 \%$ & $\mathbf{H} \mathbf{3}_{\mathbf{b}}:$ rejected \\
\hline Methods of collected information & 2.321 & 3.000 & 0.079 & $0.4 \%$ & $\mathbf{H 3}_{\mathbf{c}}:$ rejected \\
\hline Methods of analysis information & 0.848 & 3.000 & 0.470 & $1.8 \%$ & $\mathbf{H 3}_{\mathbf{d}}:$ rejected \\
\hline Methods of disseminated information & 0.629 & 4.000 & 0.643 & $0.0 \%$ & $\mathbf{H 3}_{\mathbf{e}}:$ rejected \\
\hline Methods of storage information & 1.847 & 3.000 & 0.143 & $0.0 \%$ & $\mathbf{H 3}_{\mathbf{f}}:$ rejected \\
\hline $\begin{array}{l}\text { The formalization of information } \\
\text { management }\end{array}$ & $\mathbf{1 . 0 1 0}$ & $\mathbf{5 . 0 0 0}$ & $\mathbf{0 . 4 1 5}$ & $\mathbf{0 . 6 \%}$ & $\mathbf{H 3}_{\mathbf{g}}:$ rejected \\
\hline
\end{tabular}


From the obtained results, we deduce that the asymptotic meaning is equal to $(0.751,0.432,0.079,0.470,0.643$, 0.143 and 0.415 ), they are therefore greater than 0.05 . We can thus accept the null hypothesis of the independence and invalidate $(\mathrm{H} 3 \mathrm{a}, \mathrm{H} 3 \mathrm{~b}, \mathrm{H} 3 \mathrm{c}, \mathrm{H} 3 \mathrm{~d}, \mathrm{H} 3 \mathrm{e}, \mathrm{H} 3 \mathrm{f}$ and $\mathrm{H} 3 \mathrm{~g}$ ) hypotheses. The analyses of variance carried out for the hypotheses testing relating to the links which could exist between the structure complexity and ESP variable made it possible to reject all the hypotheses formulated for this purpose. The obtained results seem to diverge with the contributions of certain theoretical works such as those of Hatch (2000) which show that the structure complexity or even, the structural differentiation can impose natural borders affecting the modes of communication and coordination in the firm. Based on this observation, we assumed during the hypotheses formulation that the structural complexity could make it difficult to send and receive the information collected as part of the business intelligence process, and may even lead to the dispersal of this information and the loss of control. The empirical results relating to the testing of the fourth hypothesis also diverge from the comments of Kourteli (2000) who indicates that the problem of splitting up the business intelligence activity is often present in complex organizations.

\section{Conclusion}

The results of the hypothesis validation relating structure centralization and ESP mean that a weak centralization, a decentralization of decision-making at the level of the subsidiary, leads necessarily to the mobilization of stakeholders with different profiles, who may collect a variety of information, use several information sources and networks, and adopt a variety of methods and tools for information collection, analysis, dissemination and storage. Concerning the second series of hypotheses concerning the link between structure formalization and environmental scanning practices, we were able to confirm the existence of all the relationships provided for between the formalization of behaviors within the subsidiary and the different variables operationalizing its ESP. Assumptions about the relationship between the vertical complexity of the structure and the ESP have been reversed. Faced with these challenges and in order to develop coordination between the company's stakeholders and improve their perception and understanding of the information collected, some companies tend to encourage the existence of certain media for storing and disseminating information such as reports, reports, memos and meetings. However, this presumed effect of structural complexity on methods of disseminating and storing information has been empirically reversed. This is due to a certain standardization of the practices and methods adopted to manage information within the subsidiaries studied despite their differences in structural complexity. It should be remembered that this observation has already been made at the descriptive analysis of the variable "formalization of information management" and the variable "complexity of the structure.

The contributions of scanning environment practices at the corporate level and in particular at the level of group subsidiaries, and to stimulate the interest of the public authorities to support the efforts made by companies in the field of strategic intelligence and thus to promote entrepreneurial prospects in this area. After seeing during our review of the literature that there are difficulties in identifying and interpreting the dimensions reflecting scanning environment practices, our study attempted to participate in a better understanding of this concept and its dimensions.

The limits of research, it is possible to consider that the dimensions used to translate ESP may be missing and that other dimensions such as the one relating to the objectives of the previous day should be taken into account in order to better understand the concept. And, despite differences in the literature regarding the role that can be played by structural formalization, we were able to confirm and justify all the hypotheses linking this structural specificity with the variables relating to ESP. From the limitations mentioned above arise some research perspectives. The first would be to reproduce this same study by integrating new variables for the understanding of the company's environmental scanning practices but also for the understanding of organizational, individual and technological specificities that could influence these informational practices.

\section{References}

Albright, K. (2004). Environmental scanning: radar for success. Information Management Journal, 38(3), 38-45. Retrieved from https://www.academia.edu/21189694/Environmental_scanning_Radar_for_success

Aldehayyat, J. S. (2014). Environmental scanning in business organisations Empirical evidence from a Middle Eastern country context. Management Research Review, 38(5), 459-481. https://doi.org/10.1108/MRR-02-2014-0032

Amabile, S., \& Guechtouli, M. (2008, September). Veille et sélection de l'information: intégrer les acteurs dans le développement de filtres informationnels intelligents. Revue Finance, Contrôle, Stratégie, 1(3), 189-215. Retrieved from https://www.researchgate.net/profile/Manelle_Guechtouli/publication/23935115_ 
Amabile, S., Laghzaoui, S., \& Boudrandi, S. (2011). Pratiques de veille stratégique par les PME exportatrices. Management \& Avenir, 4(44), 15-33. https://doi.org/10.3917/mav.044.0015

Beal, R. M. (2000). Competing effectively: Environment scanning, competitive strategy, and organizational performance in small manufacturing firms. Journal of Small Business Management, 38(1), 27-47. Retrieved from https://www.questia.com/library/journal/1G1-59282627/competing-effectively-environmental-scanning-compet itive

Bergeron, F., Raymond, L., \& Rivard, S. (2004). L'alignement stratégique des TI et la performance des PME. 13ème Conférence de l'Association Internationale de Management Stratégique AIMS, Normandie, Juin. Retrieved from https://studylibfr.com/doc/1972398/alignement-des-technologies-de-l-information

Boulifa, T. I., \& Ben Ammar-Mamlouk, Z. (2009, May-August). Identification et validation des facteurs critiques de succès pour la mise en place d'un dispositif de veille stratégique. La Revue des Sciences de Gestion, 237-238, 187-193. https://doi.org/10.1051/larsg/2009023

Brouard, F. (2000). Que la veille stratégique se lève: faisons le point sur la terminologie et le concept. Congrès ASAC-IFSAM, Montréal, Québec. Retrieved from https://carleton.ca/profbrouard/research/

Brouard, F. (2005). Création d'un outil diagnostique pour les PME et développement du savoir. ASAC, Toronto, Ontario. Retrieved from https://carleton.ca/profbrouard/research/

Brouard, F., \& Larivet, S. (2007). La veille stratégique, un outil pour améliorer la Gouvernance. Actes Electroniques du Colloque Entrepreneuriat: nouveaux enjeux, nouveaux comportements, ISC, Paris, Juin. Retrieved from https://carleton.ca/profbrouard/research/

Carricano, M., \& Poujol, F. (2008). Analyse de données avec SPSS. Pearson Education France.

Chapus, E., \& Lesca, H. (1996, September). Implantation d'une veille stratégique en coopération en milieu de PMI. Actes du 1léme Colloque International de Management des Réseaux d'Entreprises CIMRE, Lausanne, Suisse, 32. Retrieved from www.veille-strategique.org/pages/5-articles.html

Choo, C-W. (1999, February-March). The art of scanning the environment. Bulletin of the American Society for Information Science. Bulletin of the American Society for Information Science, 25(3), 21-24. https://doi.org/10.1002/bult.117

Choo, C-W. (2013). Environmental scanning by Canadian CEOS. Proceeding of the annual conference of CAIS/ACIS. https://doi.org/10.29173/cais722

Cohen, C. (2006, November). Intelligence économique et stratégique : Comment améliorer l'efficacité des l'IES et son impact sur la performance de l'entreprise. Actes du Colloque Intelligence Economique et Compétition Internationale, $\quad$ IECI, Paris, $52 . \quad$ Retrieved from https://theconversation.com/nz/topics/megadonnees-22858/articles.atom

Desreumaux, A. (1993). Stratégie. Edition Dalloz.

Dishman, P-L., \& Calof, J-L. (2008). Competitive intelligence: a multi phasic precedent to marketing strategy. European Journal of Marketing, 42(7/8), 766-785 https://doi.org/10.1108/03090560810877141

Donaldson, L. (1982). Comments on 'contingency and choice in organization theory. Organization Studies, 3(1), 65-72. https://doi.org/10.1177/017084068200300104

Du Toit, A. S. A. (2016). Using environmental scanning to collect strategic information: South African Survey. International Journal of Information Management, 36(1), 16-24. https://doi.org/10.1016/j.ijinfomgt.2015.08.005

Duncan, R-B. (1972). Characteristics of organizational environments and perceived environmental uncertainty. Administrative Science Quarterly, 17, 313-327.https://doi.org/10.2307/2392145

Finkelstein, \& Hambrick. (1996). Strategic leadership: top executives and their effects on organizations. St Paul, West Publishing.

Guechtouli, M. (2014). Management des activités de veille stratégique : entre une organisation formelle et informelle. La Revue des Sciences de Gestion, 2(266), 23-31. https://doi.org/10.3917/rsg.266.0023

Hatch, M-J. (2000). Théorie des organisations. De l'intérêt de perspectives multiples. Edition De Boeck Université.

Joffre, P., \& Koening, G. (1985). Stratégie d'entreprise. Ed. Economica, Paris.

Julien, \& Ramangalahy. (2003, April). Technological scanning by small Canadian manufacturers. Journal of Small 
Business Management, 39(2), 123-138. https://doi.org/10.1111/1540-627X.00012

Julien, P-A. (1997). Les PME: bilan et perspectives. Ed. Economica, Paris, p. 352.

Julien, P-A., Raymond, L., Jacob, R., \& Ramangalahy, C. (1999). Types of technological scanning in manufacturing SMEs: An empirical analysis of patterns and determinants. Entrepreneurship and Regional Development, 11(4), 281-300. https://doi.org/10.1080/089856299283119

Kourtelli, L. (2000). Scanning the business environment: some conceptual issues. Benchmarking, 7(5), 406-413. https://doi.org/10.1108/14635770010694340

Kumar, K., Subramabian, R., \& Strandholm, K. (2001). Competitive strategy, environmental scanning and performance: A context specific analysis of their relationship. International Journal of Commerce and Management, 11(1), 1-33. https://doi.org/10.1108/eb047413

Lawrence, \& Lorsch. (1989). Adapter les structures de l'entreprise. Les Editions d'organisation, Paris.

Mcgee, J-E., \& Sawyerr, O-O. (2003, October). Uncertainty and information search activities: a study of owner-managers of high-technology manufacturing firms. Journal of Small Business Management, 41(4), 385-401. https://doi.org/10.1111/1540-627X.00089

Messeghem, K. (2001a, September). Implications organisationnelles des normes ISO 9000 pour les petites et moyennes entreprises. Finance Contrôle Stratégie, 4(3), 183-213. Retrieved from https://www.cairn.info/revue-management-et-avenir-2011-3-page-164.htm

Messeghem, K. (2001b). Peut-on concilier logiques managériale et entrepreneuriale en PME?. 10ème Conférence de l'Association Internationale de Management Stratégique AIMS, Québec, Juin. https://doi.org/10.1051/larsg:2002011

Miller, \& Droge. (1986). Psychological and traditional determinants of structure. Administrative Science Quarterly, 31, 539-560. https://doi.org/10.2307/2392963

Mintzberg, H. (1988). Generic strategies: toward a comprehensive framework . Advances in Strategic Management, 5 , pp 1-67. https://doi.org/10.1515/9783110864519-012

Narman, P., Johnson, P., \& Gingnell, L. (2014). Using enterprise architecture to analyze how organizational structure impact motivation and learning. Enterprise Information Systems, 2014. https://doi.org/10.1080/17517575.2014.986211

Pleshko, L., \& Nickersin, I. (2008). Strategic orientation, organizational structure, and the associated effects on performance in industrial firms. Academy of Strategic Management Journal, 7, 95-110. Retrieved from http://www.i-scholar.in/index.php/johb/article/view/41064

Raymond, L., Julien, P-A., \& Ramangalahy, C. (2001, April). Technological scanning by small Canadian

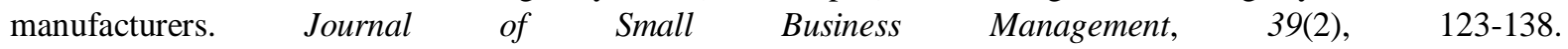
https://doi.org/10.1111/1540-627X.00012

Roiron, L., \& Lesca, H. (1996, November-December). La veille stratégique dans les entreprises Britanniques. Direction et Gestion des entreprises. Stratégie et structure, (162), 23-33. https://doi.org/10.1051/larsg:1996039

Strandholm, \& Kumar. (2003, September). Differences in environmental scanning activities between large and small organizations: the advantage of size. Journal of American Academy of Business, 3(1/2), 416-421. Retrieved from https://www.cairn.info/revue-des-sciences-de-gestion-2007-4-page-77.htm

Vergnaud Schaeffer, M-P. (1993, September-October). Veille de l'entreprise et performance. Une approche pour les PME-PMI. Direction et Gestion des Entreprises, (143), 55-67.

Weick, K-E. (1991). The non-traditional quality of organizational learning. Organization Science, 2(1), 124-166. https://doi.org/10.1287/orsc.2.1.116

Znaidi, A, B., \& Zribi, O. E. (2018). Veille stratégique: du concept à la pratique Cas de groupes d'entreprises tunisiennes. XXVIIe Conférence Internationale de Management Stratégique.

Znaidi, A., \& Gherib, D. (2019, May). Environmental Practices Scanning and CEO's profile. International Journal of Business and Management, 14(6), 160. https://doi.org/10.5539/ijbm.v14n6p160 